U.S. DEPARTMENT OF THE INTERIOR

U.S. GEOLOGICAL SURVEY

\title{
REVISED SHADED RELIEF MAP AND CONTROLLED COLOR PHOTOMOSAIC OF THE DIACRIA QUADRANGLE (MC-2) OF MARS
}

Prepared for the

NATIONAL AERONAUTICS AND SPACE ADMINISTRATION 